\title{
Food allergy and anaphylaxis - 2051. Economic burden of anaphylaxis in the United States
}

\author{
Ray Wolf ${ }^{*}$, David Alexander Sclar², Mary-Ellen Marx² \\ From 2nd WAO International Scientific Conference (WISC 2012) \\ Hyderabad, India. 6-9 December 2012
}

\section{Background}

Although the prevalence of allergy and incidence of anaphylaxis are rising globally, there exists a paucity of data as to the economic burden of anaphylaxis. This inquiry reports the estimated magnitude of national fiscal outlays (direct and indirect) in the United States (US), and intensity of demand by health service area.

\section{Methods}

We employed Monte-Carlo simulation, a decision-analytical framework parameterized by stochastic and deterministic components, to yield a national (US) burden of illness profile for anaphylaxis. Findings are based on the US population in 2010, and are reported in 2010 dollars (US). The prevalence of the at-risk population by type of exposure (food; insects; medication; latex), resulting use of health services (direct costs), and death, were discerned from national survey data from the US National Center for Health Statistics, and the medical literature. Indirect costs included lost productivity (earnings), for both patients and caregivers, and mortality. The methodology used in this study is applicable on an international basis.

\section{Results}

In 2010, the estimated US population at risk for anaphylaxis ranged between 3.7 and 48.7 million (median $=14.4$ million). The estimated incidence of anaphylaxis ranged between 50,446 and 657,330 (median $=211,874)$. Direct expenditures ranged between $\$ 288$ million and $\$ 3.7$ billion ( median $=\$ 1.2$ billion). Indirect expenditures ranged between $\$ 145$ million and $\$ 1.9$ billion (median $=\$ 609$ million). The point-estimate for direct expenditures for epinephrine was $\$ 294$ million. Net of the point-estimate for direct expenditures of epinephrine, and accounting for biphasic anaphylaxis, both direct and indirect expenditures

${ }^{1}$ Medical Affairs, Mylan Specialty L.P., Basking Ridge, NJ, USA

Full list of author information is available at the end of the article far exceeded the expenditure of equipping at-risk patients with epinephrine autoinjectors.

\section{Conclusions}

The extent of under-diagnosis and under-reporting of anaphylaxis in the US precludes an exacting measure of the burden of illness. Our results suggest the burden of illness due to anaphylaxis in the US is far greater than previously reported. Similar results may apply internationally.

\section{Author details}

${ }^{1}$ Medical Affairs, Mylan Specialty L.P., Basking Ridge, NJ, USA. ²Department of Health Policy \& Administration, Washington State University, Spokane, WA, USA.

Published: 23 April 2013

doi:10.1186/1939-4551-6-S1-P134

Cite this article as: Wolf et al:: Food allergy and anaphylaxis - 2051.

Economic burden of anaphylaxis in the United States. World Allergy Organization Journal 2013 6(Suppl 1):P134.
Submit your next manuscript to BioMed Central and take full advantage of:

- Convenient online submission

- Thorough peer review

- No space constraints or color figure charges

- Immediate publication on acceptance

- Inclusion in PubMed, CAS, Scopus and Google Scholar

- Research which is freely available for redistribution
C Biomed Central

\section{Biomed Central}

(c) 2013 Wolf et al; licensee BioMed Central Ltd. This is an Open Access article distributed under the terms of the Creative Commons Attribution License (http://creativecommons.org/licenses/by/2.0), which permits unrestricted use, distribution, and reproduction in any medium, provided the original work is properly cited. 